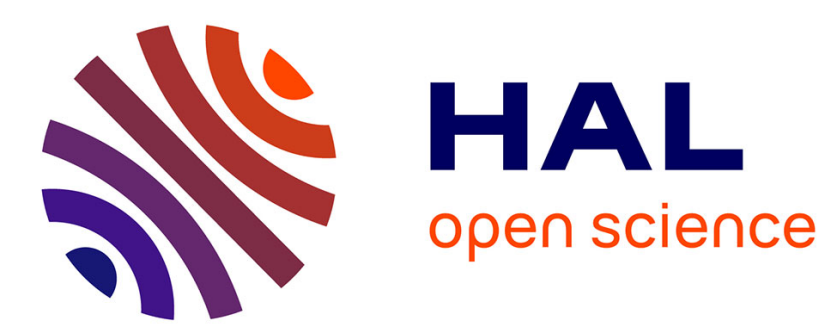

\title{
Why CEOs Resign: Poor Performance or Better Opportunities?
}

Nikos Bozionelos, Sumona Mukhuty

\section{To cite this version:}

Nikos Bozionelos, Sumona Mukhuty. Why CEOs Resign: Poor Performance or Better Opportunities?: Research Brief. Academy of Management Perspectives, 2015, 29 (1), 10.5465/amp.2015.0039 . hal01145842

\section{HAL Id: hal-01145842 \\ https://hal-audencia.archives-ouvertes.fr/hal-01145842}

Submitted on 27 Apr 2015

HAL is a multi-disciplinary open access archive for the deposit and dissemination of scientific research documents, whether they are published or not. The documents may come from teaching and research institutions in France or abroad, or from public or private research centers.
L'archive ouverte pluridisciplinaire HAL, est destinée au dépôt et à la diffusion de documents scientifiques de niveau recherche, publiés ou non, émanant des établissements d'enseignement et de recherche français ou étrangers, des laboratoires publics ou privés. 


\title{
Why CEOs Resign: Poor Performance or Better Opportunities?
}

\author{
Nikos Bozionelos \\ Professor of Organizational Behavior and Human Resource Management, \\ Audencia School of Management, \\ Nantes, 44312, France \\ e-mail:nbozionelos@audencia.com \\ Sumona Mukhuty \\ Assistant Professor in Organizational Behavior, \\ Hull University Business School, University of Hull, \\ Hull, HU6 7RX, United Kingdom \\ e-mail: s.mukhuty@hull.ac.uk
}

\section{Research Questions}

Why do CEOs resign? This is an important question given the impact CEOs have economically and in society (Hambrick \& Quigley, 2014). A common view is that CEOs resign because shareholders and the board want them to leave because of lower-thanexpected performance. The implication here is that power resides with shareholders and the board, with CEOs sitting around passively waiting for their fates to be decided. After all, CEOs are compensated extremely well for delivering results. So it seems only fair that their positions are precarious and in the hands of shareholders and board members. Yet in many cases, the reasons CEOs resign are murky and appear to have little to do with performance. Consequently, in a recent paper, Yun Liu from the University of California at Riverside 
challenged the dominant notion that CEO resignations are shareholder and board driven. Instead, Liu attempted to shed more light on why CEOs resign by adopting their perspective. Specifically, Liu argues that CEOs often resign not because they are forced out, but because they find better deals elsewhere. Liu based his premise on employment contracting theory, particularly its idea of "participation constraint." Basically, the notion is that someone will stick with a current employment contract as long as he or she believes they are not worse off relative to outside opportunities. When, and if, someone perceives that better prospects exist elsewhere, then the current contract may be abandoned. In the case of CEOs, this simply means that CEOs may leave because they can land better deals in other firms or institutions.

But since executive and director positions are rarely advertised and few and far between to begin with, how do CEOs obtain information about such opportunities elsewhere? Liu believes that access to such information comes from CEOs own personal networks or "connectedness." We know that connectedness generally plays a role in finding employment and moving up the corporate ladder (Bozionelos, in press). However, Liu considers that connectedness is particularly important for CEOs because most information on executive openings is not publicly available. Furthermore, being an executive and overtly looking for employment opportunities involves some risk (e.g., one's motives and loyalties may be questioned). Finally, unlike most other types of hiring, there is very little margin for error when it comes to CEOs - an outstanding fit between candidate and position is imperative. Consequently, connectedness may be crucial both for executives on the lookout for new opportunities and for firms seeking to fill executive positions.

In a nutshell, Liu developed and tested the idea that CEOs with richer networks are more likely to leave their firm for an opportunity elsewhere.

\section{Study Design \& Method}


Liu used the Board Ex database to extract detailed information on more than 7,500 CEOs from nearly 5,000 publicly held firms over an 18-year period (1991-2009). During this timeframe, nearly 3,000 CEO resignations took place in the firms studied.

Liu also used the database to construct the personal networks or connectedness of these CEOs. Subsequently, Liu linked these data with data from other databases, such as Compustat and CRSP, which provide financial information on the firms involved. On average, each CEO had ties with 12 other executives in each given year. Liu measured connectedness with an index that reflects the richness or variety of information CEOs have access to. The more varied the information a CEO can access via his or her ties with directors outside and inside the firm, the greater their connectedness. Liu investigated the relationships between CEOs' connectedness and their mobility up to two years after their resignations from their current position. In his calculations, Liu took into account characteristics of both firms and of CEOs themselves (such as education and personality). As a result, he was able to isolate the influence of connectedness on mobility and produce generalizable conclusions.

Liu identified three types of destinations for CEOs who resigned. About two thirds of these CEOs took positions internal to the firm, usually chairman of the board or executive director. About $20 \%$ took full-time positions outside the firm--normally CEO positions in other firms. Finally, almost a third of the sample took part-time positions outside the firm, normally non-executive directorships in other firms. There was also a respectable proportion of CEOs (about 14\%) who took no new position after resigning. An interesting finding was that those aged 60 and above were more likely to hold a new position two years after resigning than those below 60 ! This illustrates that CEOs who leave at "normal" retirement age (that is 60 and above) remain very active in their work lives, perhaps more active that their much younger counterparts. 


\section{Key Findings}

Liu's findings confirmed that the greater the CEO connectedness the greater the probability of CEO resignation. Indeed, for every one standard deviation increase in connectedness the chance of CEO resignation increased roughly $10 \%$. This was in line with Liu's idea that CEO resignations are often driven by their connectedness. Interestingly, connectedness with other executives inside the firm reduced the probability of CEO resignation. So on the one hand, richer links with executives in other firms seem to increase the likelihood that CEOs will leave while stronger connections within the firm seem to make it less likely. That said, the results also showed that a substantial proportion of CEO resignations were indeed linked to poor firm performance, which is in line with common perceptions about why CEOs leave.

Next, Liu tested whether resignations were related to the nature of external opportunities available (full-time or part-time) via connectedness. His results showed that CEO connectedness increased the probability of resignation for a full-time position elsewhere (such as becoming CEO in another firm) only for CEOs below 60 years of age. Similarly, a decline in firm performance was associated with increased probability of CEO resignation, but again mostly for "young" CEOs. These findings basically mean that "young” CEOs are more likely to use their connections in order to find more alluring CEO positions in other firms. On the other hand, the reverse pattern was found for part-time positions. In short, "old" CEOs were more likely to use their connections to become non-executive directors in other firms. Such positions include good financial packages and prestige, but are less time demanding - perhaps ideal for CEOs at retirement age.

So the results clearly suggested that connectedness may help identify alternative opportunities for CEOs, prompting them to resign to take CEO positions in other firms or to retire and take a non-executive position somewhere else. Naturally the next issue that Liu 
examined was which explanation - outside opportunities or poor performance -weighs heavier in CEO resignations. Importantly, his analysis showed that connectedness increased the probability of resignation to seek a CEO or non-executive position somewhere else more than poor performance did.

In the final step, Liu investigated whether connectedness was related to probability of resignation under particular conditions of firm performance. As it turned out, while CEO connectedness was related to the probability of CEO resignation under all performance conditions (poor, medium and strong), the relationship was especially strong when firms were performing poorly.

According to Liu this may mean that well-performing CEOs have less need to rely on their connections to move to other firms because their records will "speak for themselves."

On the other hand, poor performers must counterbalance their poor outcomes with additional information if they are to move on--and their networking serves as a conduit for transmitting such information. Furthermore, Liu pointed out that high performing CEOs may find it best to continue with their current firms because those firms are likely to reward them with even better conditions and pay. On the other hand, poorly performing CEOs may have limited futures within the firm and may also experience internal pressure to resign. This may leave them with few alternatives other than any outside opportunity that they learn about through their networks.

\section{Conclusions \& Implications}

CEO turnover is an important corporate event. Liu explored a new dimension in CEO resignation by taking the perspective of CEOs themselves and considering them as actors that shape their own future rather than as passive objects who simply react to board demands and decisions. His findings suggested that options outside their current firm influence CEOs resignations beyond their performance. This means that in many cases CEOs leave not 
because they are fired but because their networks with other executives help them uncover better opportunities outside their firms.

Overall, well-connected CEOs appear more likely to leave their firms than poorly connected ones. In addition, poor performing CEOs seem especially keen to use their networks to find external jobs, probably because of limited internal opportunities and pressure to leave. And while well-performing CEOs with richer networks may also leave, they will likely have more to gain by staying put.

\section{References}

Bozionelos, N. (in press). Social capital and careers: Indisputable evidence and note for caution. In De Vos, A. \& Van der Heijden B. I. J. M. (Eds.), Handbook of Research on Sustainable Careers. Cheltenham, UK: Edward Elgar Publishing.

Hambrick, D. C., \& Quigley, T. J. (2014). Toward more accurate contextualisation of the CEO effect on firm performance. Strategic Management Journal, 35, 473 - 491.

Liu, Y. (2014). Outside options and CEO turnover: The network effect. Journal of Corporate Finance, 28, 201-217. 